\title{
Learning styles and intelligence types versus academic performance of nursing students of the University of Zambia
}

\author{
Patricia Katowa-Mukwato, Fabian Chapima, Brenda Nambala-Sianchapa, Victoria Mwiinga-Kalusopa \\ School of Nursing Sciences, University of Zambia, Lusaka, Zambia
}

Received: April 23, 2017

DOI: $10.5430 /$ jnep.v7n10p83

\author{
Accepted: May 9, 2017 \\ Online Published: May 23, 2017 \\ URL: https://doi.org/10.5430/jnep.v7n10p83
}

\begin{abstract}
Background: Learning styles are inherent personal attributes that determine the preferred teaching and learning method(s) for individual while an intelligence type is an individual's levels of aptitude in various content areas as there is no one individual who is universally intelligent. An understanding of the two concepts is essential for designing suitable teaching approaches.

Methods: This was a descriptive correlation study which explored the relationship between two variables; learning styles and intelligence types and academic performance of nursing students enrolled in the conventional nursing program at the University of Zambia. Data on learning styles was collected using the Visual, Auditory, Reading/Writing and Kinesthetic (VARK) questionnaire version 7.8 as proposed by Neil Fleming while Gardner's questionnaire for assessing multiple intelligences was used to collect data on the students' intelligence types. Results for the end of 2015/2016 academic year were used to determine academic performance.

Results: Almost two thirds 64 (65.4\%) of the participants' academic performance was at credit level, 32 (32.7\%) were at pass while only $2(2 \%)$ were meritorious students. Participants had wide-ranging learning styles from unimodal, to bimodal and tri modal styles, although the majority were unimodal learners 81 (82.6\%). Among the unimodal learners, majority 35 (35.5\%) were kinaesthetic. On the other hand, 37 (37.8\%) had logical mathematical intelligence, followed by bodily-Kinaesthetic 27 (27.6\%). Both learning styles and intelligence types showed negative correlation and no significant association with academic performance. The Pearson $r$ correlation and level of significance between learning styles and academic performance was -.092 and 0.372 respectively, while that for intelligence types and academic performance were -.027 and 0.790 . Of the three demographic variables of age, gender and year of study, only age showed a positive correlation and significant association with academic performance ( $p=.002$, and $r=.144)$.

Conclusions: The negative correlation between learning styles and intelligence types and academic performance may be an indication that the teaching methods utilized for nursing students are varied and therefore capable of promoting learning across different styles and intelligence types without necessarily favouring a specific style or type or that there is simply no association between learning styles and intelligence types and academic performance.
\end{abstract}

Key Words: Learning styles, Intelligence types, Nursing students, Academic performance

\section{BACKGROUND}

The concept that individuals have preferred approaches to learning based on the individual's perception of a situation is referred to as learning or cognitive style. ${ }^{[1]}$ Learning style have been defined as "a combination of cognitive, affective, and physiological characteristics that serve as relatively sta-

\footnotetext{
* Correspondence: Patricia Katowa-Mukwato; Email: patriciakatowamukwato@gmail.com; Address: School of Nursing Sciences, University of Zambia, Lusaka, Zambia.
}

Published by Sciedu Press 
ble indices in relation to how people receive information and interact with it and respond to the learning environment". [1] In 2005, Larkin and Budny stated that a "learning style is a biologically and developmentally imposed set of personal characteristics that make the same teaching and learning methods effective for some and ineffective for others". ${ }^{[2]}$ Learning-style theory can be traced back to Carl Jung 1927 who noted major differences in the way people perceived (sensation versus intuition), the way they made decisions (logical thinking versus imaginative feelings), and how active or reflective they were while interacting (extroversion versus introversion). ${ }^{[3]}$ In the field of education, the concept of learning styles has been recognized since the mid-1970s. ${ }^{[4]}$

Understanding the internal and external factors that affect the way individuals learn is essential in helping to improve their interaction within education environments. ${ }^{[5]}$ In addition, knowledge of learning styles may help educators identify and solve learning problems among students, thus helping their students to become more effective learners. ${ }^{[6,7]}$ If learning styles are neglected, it may hinder students' learning as teachers may present content in styles that do not match student's preferred learning styles. ${ }^{[8]}$ On the other hand, knowledge of learning styles helps teachers to reach out to more students and help them learn. ${ }^{[9]}$

Based on the understanding of the individual differences in learning, educators have recognized the importance of adapting or individualizing instructional methods to address individual differences in ability level, developmental level, and level of prior knowledge. ${ }^{[10]}$ Additionally, over the past two decades, educational researchers and practitioners have confirmed that individuals not only differ in ability level, but also differ systematically in their patterns of behaviour or responses to similar situations, reflecting an underlying style. Therefore diagnosing students' learning styles and matching them to teaching methods (for example, for a 'visual learner', presenting information through pictorial illustrations), can greatly enhance learning. ${ }^{[11]}$ However, it is also important to note that other scholars have rejected the value of learning styles in education and have claimed that tailoring teaching methods to students' individual learning styles does not lead to better learning outcomes. ${ }^{[12]}$

In educational literature, the commonly agreed upon model of learning style is the Fleming (2006) model that proposes that learning is composed of four styles; Visual (V), Aural/auditory (A), reading/writing (R) and kinesthetic (K) commonly abbreviated as (VARK). Visual (V) learners learn best using their sense of sight. According to the Fleming model, learners have different preferred ways of learning, for example visual learners learn best by viewing the learning materials presented in form of demonstrations, videos, and films. ${ }^{[13]}$ Similarly, Mayzler and McGann affirmed that the visual learner is a person who learns best when she or he is seeing the information - the brain absorbs the information best when the information is delivered through the sense of sight ${ }^{[14]}$ or learners who prefer pictorial information. ${ }^{[15]}$

For Aural (A) learners, the learning process is enhanced when information is delivered through the sense of hearing. They prefer information delivered through lectures, discussions, conversations in class or in a recorded format. ${ }^{[16]}$ Equally other scholars have suggested that aural learners unlike visual learners prefer to listen to lectures before reading lecture notes and their understand of learning materials improve after listening and asking/answering questions loudly. ${ }^{[17]}$ Aural Learners have been reported to have excellent listening skills, not only recalling what was said, but they have unique ability to catch hints in words, tone, inflection and overall meaning from the speaker. ${ }^{[18]}$ Aural learners like listening to themselves. They can be identified through the verbalizations they make often through singing or talking to oneself and repeating what they hear from their teachers.

According to the Fleming model, Read/write (R) learners, learn best when information is delivered to them as written words. ${ }^{[19]}$ Students who learn best using this style prefer the written word attained through reading or writing information. ${ }^{[20]}$ Such learners perform well in situations where they are required to read or write down information because they store information as organized in sets of symbols ${ }^{[21]}$ which they can easily recall. On the other hand Kinaesthetic (K) learners also referred to as tactile learners, use body movements and bodily sensations to learn. ${ }^{[22]}$ Kinaesthetic learners learn best with the physical experience attained through touching, feeling, holding, doing, and practical hand-on experience. ${ }^{[23]}$ Other scholars have stated that kinaesthetic learner learn through movement ${ }^{[24]}$ while others have described kinaesthetic students as learners who learn by doing. ${ }^{[25]}$

According to the VARK model, ${ }^{[19]}$ a learner can prefer only one learning style such as Visual (V), or any combination of two styles such as Visual and Aural (VA), or combination of three for example Visual, Aural and Kinaesthetic (VAK) or utmost all the four styles of Visual, Aural, Writing/Reading and Kinaesthetic (VARK). Learners who learn best using one mode are referred to as single modal learners, those who prefer two modes as bimodal, those for three as tri-modal, while those who can utilize all the four different styles are quad modal learners. Learners who use two or more styles to acquire information are called multimodal learners which include bimodal, tri-modal and quad-modal learners. Multimodal learners have no single preferred learning style, but 
prefer a combination of different styles.

Scholars have suggested that a better understanding of the learning styles of students by teaching staff can reduce the level of dissatisfaction amongst students, and improve teaching outcomes. ${ }^{[1,26]}$ Similarly, others scholars have asserted that in order to improve academic performance and achieve desired learning outcomes, teachers must present content in a style that matches student's preferred learning. ${ }^{[27]}$ In addition to the VARK learning styles as expounded by Fleming, other scholars such as Kolb in his learning style inventory categorize learning styles as converging (best in finding practical uses for the learning), diverging (tending to gather information and use imagination to solve problems), assimilating (focus on concise, logical approach with ideas and concepts being more important than people), and accommodating (hands-on', and relies on intuition rather than logic). ${ }^{[28]}$ However for this study, Fleming's VARK learning styles was used for identifying and classifying nursing students' learning styles.

In addition to understanding learning styles as a foundation for designing suitable teaching approaches, educators need to know their learners' intelligence type in order to adapt an appropriate teaching approach. The theory of multiple intelligences is closely related to Howard Gardner. Gardner describes seven intelligences: linguistic, logical-mathematical, spatial, musical, bodily-kinesthetic, interpersonal, and intrapersonal. ${ }^{[3]}$ Gardner's seven intelligences are not abstract concepts, but are recognizable through common life experiences. For example everyone shows different levels of aptitude in various content areas. In all cases, we know that no individual is universally intelligent; certain fields of knowledge engage or elude everyone. Gardner groups student capabilities into seven broad categories. These include: musical intelligence, logical-mathematical intelligence, interpersonal intelligence, bodily-kinesthetic intelligence, linguistic intelligence, intra-personal intelligence and spatial intelligence. ${ }^{[29]}$

According to Gardner, musical intelligence also known as musical smart" is the intelligence involving the capacity to distinguish pitch, rhythm, and tone. This intelligence enables us to recognize, create, reproduce, and reflect on music. $\mathrm{Mu}-$ sic composers, musicians, and sensitive listeners possess this type of intelligence and students with this kind of intelligence are usually singing or drumming to themselves.

Logical-mathematical intelligence people have an ability to calculate, quantify, consider propositions and hypotheses, and carry out mathematical operations. Such individuals are able to perceive relationships and connections and to use abstract, symbolic thoughts; sequential reasoning skills; and inductive and deductive thinking patterns. Logical intelli- gence is usually well developed in mathematicians, scientists, and detectives. Students with lots of logical intelligence are interested in patterns, categories, and relationships. They are interested in arithmetic problems, strategy games and experiments. While interpersonal intelligence (People Smart) is the ability to understand and interact effectively with others. It involves effective verbal and nonverbal communication, sensitivity to the moods and temperaments of others, and the ability to entertain multiple perspectives. This type of intelligence is demonstrated by teachers, social workers, actors, and politicians. Young adults with this kind of intelligence are leaders among their peers, are good at communicating, and seem to understand others' feelings and motives.

Bodily-Kinesthetic intelligence "Body Smart" is the unique ability to use a variety of physical skills. This intelligence also involves a sense of timing and the perfection of skills through mind-body union. Athletes, dancers, surgeons, and nurses exhibit well-developed bodily kinesthetic intelligence. On the other hand linguistic intelligence (Word Smart) is the ability to think in words and use language to express and appreciate complex meanings. Linguistic intelligence allows us to understand the order and meaning of words. This is the most widely shared human competence and manifests in poets, novelists, journalists and effective public speakers. Students with this kind of intelligence enjoy writing, reading, telling stories or doing crossword puzzles.

In intra-personal intelligence (Self Smart), students have the capacity to understand oneself and one's thoughts and feelings, and to use such knowledge in planning and directing one's life. Intra-personal intelligence involves not only an appreciation of the self, but also of the human condition. It is evident in nurses, psychologist or spiritual leaders. These students may be shy but are aware of their own feelings and are self-motivated.

Spatial intelligence (Picture Smart) students according to Gardner have the ability to think in three dimensions. These include mental imagery, spatial reasoning, image manipulation, graphic and artistic skills, and an active imagination. Professionals with spatial intelligence include sailors, pilots and architects.

The main aim of this study was therefore to determine the learning styles and types of intelligence of undergraduate nursing students and their effect on academic performance.

\section{Methods}

\subsection{Study design and setting}

This was a descriptive correlation study which explored the relationship between two variables: learning styles and intelligence types and academic performance of nursing students 
enrolled in conventional nursing education program at the University of Zambia. This site was purposefully selected because since the University of Zambia, School of Nursing Sciences started offering Bachelor of Science Degrees in nursing in 1981; no deliberate inquiry had been undertaken to establish the learning styles nor the predominant intelligence types of nursing students in relation to academic performance.

\subsection{Study population}

The study population were all the (146) 3rd to 5th year nursing students who are studying for a Bachelors Degree under the full time mode. The study therefore included all students who had spent at least one academic year in the School of Nursing Sciences and had written at least one end of year examination from which their academic performance was measured.

\subsection{Data collection tools}

Data on students' learning styles was collected using the Visual, Auditory, Reading/Writing and Kinesthetic (VARK) questionnaire (version 7.8) as proposed by Neil Fleming. ${ }^{[30]}$ Data on the students' intelligence types was collected using Gardner's questionnaire for assessing multiple intelligences.
For easy administration, the two questionnaires were merged into one with three sections. Section A obtained information on relevant demographic data for students. Section B comprised of the VARK questions while Section $\mathrm{C}$ had questions from Gardner's multiple intelligence questionnaire. Both the internal validity, suitability and reliability of the VARK questionnaire as an instrument for measuring learners' preferences for receiving and processing information has been support in literature. ${ }^{[31]}$ While the Cronbach's alpha coefficients for Gardner's multiple intelligence questionnaire for the seven different types of intelligence ranges from .63 to .87. ${ }^{[32]}$

Academic performance on the other hand was determined using the end of 2015/2016 academic year results for both theoretical and practical examination. Academic performance was measured using the university grading system which allocates points to examination scores as indicated in Table 1. The scoring system accounted for all the courses a student was taking in that academic year, which meant that the more points a student had the better the academic performance. The maximum score per subject was 5 points as indicated in Table 1; therefore a student who was taking 5 subjects could accrue a total of 25 points.

Table 1. Determination of academic performance

\begin{tabular}{llll}
\hline No & Examination Score in Percentage & Description & Accrued Points \\
\hline 1 & $90-100$ & Upper Distinction & 5 \\
2 & $80-89$ & Lower distinction & 4 \\
3 & $70-79$ & Merit & 3 \\
4 & $60-69$ & Credit & 2 \\
5 & $55-59$ & Absolute Pass & 1 \\
6 & $50-54$ & Bare Pass & 0 \\
7 & $0-49$ & Fail & 0 \\
\hline
\end{tabular}

Following the computation of scores, the total number of points accrued was re-categorised to define the student's academic performance as follows: $20-25$ points (Distinction), 15-19 points (Merit), 10-14 points (Credit) and 0-9 points (Pass). It was these categories which were finally compared to see if they related to different learning styles and/or different intelligence types.

\subsection{Data analysis}

Data were analysed using SPSS version 20. Then Pearson's correlation test was used to test for association between variables that included academic performance (dependent variable), learning styles and intelligence types (independent variables). In addition, Pearson's correlation test was also performed to test the association between the dependent vari- able and a few specific independent variables including age, gender and year of study. Data is presented in frequency tables and cross tabulation tables. The findings were said to be correlating when the value had a positive sign written as e.g. (.145) and were not correlating when the value had a negative sign written as e.g. (-.145). A $p$-value of .005 or less was taken as significant.

\section{RESULTS}

Out of the total student population of 136, 98 answered the self administered questionnaire on learning styles and intelligence types, which gave a response rate of $72 \%$. The response rate would have been higher, however some students opted out of the study, because they were not willing 
to have their results retrieved and be used to compare with their learning styles and intelligence types. The 98 were the only ones who were willing to answer both the self administered questionnaire and consented to the use of their end of year results to compare their learning styles and intelligence types to their performance. Of the 98, $67(68.4 \%)$ were females against 31 (31.6\%) males. About 45 (45.9\%) were aged between 18-30 years while $53(54.1 \%)$ were aged above 30 . Regarding the year of study, the distribution was as follows: $13(13.3 \%)$ were in third year, $30(30.6 \%)$ were in fourth year while $55(56.1 \%)$ were in the fifth and final year of training. More than half $54(55.1 \%)$ of the participants were in-service students, that is they were admitted to the university with prior training in nursing-they possessed Diploma qualifications in nursing and were now pursuing their first Bachelors' Degrees, while 43 (43.9\%) were pre- service students or school leavers who were admitted to the University without any prior training in Nursing. One (1\%) did not indicate his/her status. When academic performances were computed using the criteria indicated in Table 1, almost two thirds $64(65.4 \%)$ of the participants' performance was at credit level, $32(32.7 \%)$ were at pass while only $2(2 \%)$ were meritorious students.

With regard to learning styles, the participants had wideranging learning styles from unimodal to bimodal and trimodal styles although the majority were unimodal type of learners $81(82.6 \%)$. As desired for nursing students and considering that majority of the participants had prior nursing training 35 (35.5\%) of the unimodal learners were kinaesthetic followed by $20(20.4 \%)$ reading and writing type, 15 $(15.3 \%)$ auditory learners, and $11(11.2 \%)$ visual, with a few bimodal and trimodal learners as shown in Table 2.

Table 2. Respondents' learning styles $(\mathrm{N}=98)$

\begin{tabular}{llll}
\hline & Frequency & Percentage (\%) \\
\hline & Visual learning style & 11 & 11.2 \\
& Auditory learning style & 15 & 15.3 \\
& Reading and writing learning style & 20 & 20.4 \\
& Kinaesthetic learning style & 35 & 35.7 \\
& Visual, reading and writing learning style & 1 & 3.0 \\
& Visual and kinaesthetic learning style & 3 & 2.0 \\
& Auditory, reading and writing learning style & 2 & 3.1 \\
& Auditory and kinaesthetic learning style & 3 & 5.1 \\
& Reading, writing and kinaesthetic learning style & 5 & 2.0 \\
& Visual, audio and kinaesthetic & 2 & 1.0 \\
& Audio, reading and writing and kinaesthetic & 1 & $\mathbf{1 0 0 . 0}$ \\
\hline
\end{tabular}

On the other hand majority of the participants 37 (37.8\%) had logical mathematical intelligence, interesting followed by bodily-Kinaesthetic $27(27.6 \%)$ while the combination of the two; Logical-mathematical and Bodily-kinaesthetic was the third commonest type of intelligence with 24 (24.5\%) participants as shown in Table 3.

Table 3. Respondents' intelligence types $(\mathrm{N}=98)$

\begin{tabular}{llll}
\hline & Frequency & Percentage (\%) \\
\hline \multirow{2}{*}{ Intelligence types } & 37 & 37.8 \\
& Logical-Mathematical & 4 & 4.1 \\
& Musical & 27 & 27.6 \\
& Bodily-Kinaesthetic & 24 & 24.5 \\
& Logical-mathematical and Bodily-kinaesthetic & 1 & 1.0 \\
& Logical-mathematical and Interpersonal & 1 & 1.0 \\
& Bodily-kinaesthetic and Intrapersonal & 1 & 1.0 \\
& Musical, body kinaesthetic and logical mathematical & 2 & 2.0 \\
& Missing & 1 & 1.0 \\
Total & $\mathbf{9 8}$ & $\mathbf{1 0 0 . 0}$ \\
\hline
\end{tabular}


We tested our hypothesis by correlating the two independent variables; learning styles and intelligence types with academic performance and results are shown in Tables 4 and 5. Both variables showed negative correlation and no significant association. The correlation and level of significance between learning styles and academic performance was -.092 and 0.372 respectively, while the two values for intelligence types and academic performance were -.027 and 0.790 . In addition to correlating the learning styles and intelligence types with academic performance, we also correlated academic performance with some selected demographic variables of age, gender and year of study. Of the three demographic variables, only age showed a significant association with academic performance; $p$-value .002, and Pearson's correlation .144. The correlation for academic performance and gender was .121 and $p$-value at .27 , while that for academic performance and year of study were .144 and $p$-value at .156.

Table 4. Respondents' academic performance versus learning styles $(\mathrm{N}=98)$

\begin{tabular}{|c|c|c|c|c|c|c|c|c|c|c|c|c|c|c|c|}
\hline & & \multicolumn{11}{|c|}{ Type of learning styles } & \multirow[b]{2}{*}{$\begin{array}{l}\text { Total } \\
\text { n (\%) }\end{array}$} & \multirow[b]{2}{*}{$r$} & \multirow[b]{2}{*}{$p$} \\
\hline & & $\begin{array}{l}\text { VLs } \\
\text { n (\%) }\end{array}$ & $\begin{array}{l}\text { ALs } \\
\text { n (\%) }\end{array}$ & $\begin{array}{l}\text { R\& } \\
\text { WLs } \\
\text { n (\%) }\end{array}$ & $\begin{array}{l}\text { KLs } \\
\text { n (\%) }\end{array}$ & $\begin{array}{l}\text { VR\& } \\
\text { WLs } \\
\text { n (\%) }\end{array}$ & $\begin{array}{l}\text { VKLs } \\
\text { n (\%) }\end{array}$ & $\begin{array}{l}\text { A,R\& } \\
\text { WLs } \\
\text { n (\%) }\end{array}$ & $\begin{array}{l}\text { AKLs } \\
\text { n (\%) }\end{array}$ & $\begin{array}{l}\text { RWKLs } \\
\text { n (\%) }\end{array}$ & $\begin{array}{l}\text { VAKLs } \\
\text { n (\%) }\end{array}$ & $\begin{array}{l}\text { AR\&W } \\
\text { \&KLs } \\
\text { n (\%) }\end{array}$ & & & \\
\hline \multirow{3}{*}{$\begin{array}{l}\text { Academic } \\
\text { Perfor- } \\
\text { mance }\end{array}$} & $\begin{array}{l}\text { Merito- } \\
\text { rious }\end{array}$ & $\begin{array}{l}0 \\
(0)\end{array}$ & $\begin{array}{l}0 \\
(0)\end{array}$ & $\begin{array}{l}1 \\
(50)\end{array}$ & $\begin{array}{l}0 \\
(0)\end{array}$ & $\begin{array}{l}0 \\
(0)\end{array}$ & $\begin{array}{l}0 \\
(0)\end{array}$ & $\begin{array}{l}0 \\
(0)\end{array}$ & $\begin{array}{l}0 \\
(0)\end{array}$ & $\begin{array}{l}1 \\
(50)\end{array}$ & $\begin{array}{l}0 \\
(0)\end{array}$ & $\begin{array}{l}0 \\
(0)\end{array}$ & $\begin{array}{l}2 \\
(2)\end{array}$ & \multirow{4}{*}{-.092} & \multirow{4}{*}{.372} \\
\hline & Credit & $\begin{array}{l}9 \\
(14)\end{array}$ & $\begin{array}{l}10 \\
(15.6)\end{array}$ & $\begin{array}{l}10 \\
(15.6)\end{array}$ & $\begin{array}{l}27 \\
(42)\end{array}$ & $\begin{array}{l}1 \\
(1.6)\end{array}$ & $\begin{array}{l}1 \\
(1.6)\end{array}$ & $\begin{array}{l}1 \\
(1.6)\end{array}$ & $\begin{array}{l}1 \\
(1.6)\end{array}$ & $\begin{array}{l}3 \\
(4.7)\end{array}$ & $\begin{array}{l}0 \\
(0)\end{array}$ & $\begin{array}{l}1 \\
(1.6)\end{array}$ & $\begin{array}{l}64 \\
(65)\end{array}$ & & \\
\hline & Pass & $\begin{array}{l}2 \\
(6)\end{array}$ & $\begin{array}{l}5 \\
(15.6)\end{array}$ & $\begin{array}{l}9 \\
(28)\end{array}$ & $\begin{array}{l}8 \\
(25)\end{array}$ & $\begin{array}{l}0 \\
(0)\end{array}$ & $\begin{array}{l}2 \\
(6)\end{array}$ & $\begin{array}{l}1 \\
(3)\end{array}$ & $\begin{array}{l}2 \\
(6)\end{array}$ & $\begin{array}{l}1 \\
(3)\end{array}$ & $\begin{array}{l}2 \\
(6)\end{array}$ & $\begin{array}{l}0 \\
(0)\end{array}$ & $\begin{array}{l}32 \\
(33)\end{array}$ & & \\
\hline Total & & 11 & 15 & 20 & 35 & 1 & 3 & 2 & 3 & 5 & 2 & 1 & $\begin{array}{l}98 \\
(100)\end{array}$ & & \\
\hline
\end{tabular}

Note. $\mathrm{Vl}$ = Visual Learners, $\mathrm{Al}$ = Auditory Learners, R\&WLs = Reading and Writing Learners, Kls Kinaesthetic Learners.

Table 5. Respondents' academic performance versus intelligence types $(\mathrm{N}=98)$

\begin{tabular}{|c|c|c|c|c|c|c|c|c|c|c|c|c|c|}
\hline & & \multicolumn{9}{|c|}{ Intelligence types } & \multirow[b]{2}{*}{$\begin{array}{l}\text { Total } \\
\text { n (\%) }\end{array}$} & \multirow[b]{2}{*}{$r$} & \multirow[b]{2}{*}{$p$} \\
\hline & & $\begin{array}{l}\text { Logical- } \\
\text { Mathe- } \\
\text { matical } \\
\text { n (\%) }\end{array}$ & $\begin{array}{l}\text { Musi- } \\
\text { cal } \\
\text { n (\%) }\end{array}$ & $\begin{array}{l}\text { Bodily- } \\
\text { Kinaes- } \\
\text { thetic } \\
\text { n (\%) }\end{array}$ & $\begin{array}{l}\text { Logical- } \\
\text { mathematical } \\
\text { \& Bodily- } \\
\text { Kinaesthetic } \\
\text { n (\%) }\end{array}$ & $\begin{array}{l}\text { Logical- } \\
\text { Mathema- } \\
\text { tical and } \\
\text { Inter- } \\
\text { personal } \\
\text { n (\%) } \\
\end{array}$ & $\begin{array}{l}\text { Logical- } \\
\text { mathematical } \\
\text { and Intra- } \\
\text { personal } \\
\mathrm{n}(\%)\end{array}$ & $\begin{array}{l}\text { Bodily- } \\
\text { kinaesthetic } \\
\text { and Intra- } \\
\text { personal } \\
\text { n(\%) }\end{array}$ & $\begin{array}{l}\text { Musical, body } \\
\text { kinaesthetic } \\
\text { and logical } \\
\text { mathema- } \\
\text { tical } \\
\text { n (\%) } \\
\end{array}$ & $\begin{array}{l}\text { Missing } \\
\text { n (\%) }\end{array}$ & & & \\
\hline \multirow{3}{*}{$\begin{array}{l}\text { Academic } \\
\text { Perfor- } \\
\text { mance }\end{array}$} & Meritorious & $0(0)$ & $0(0)$ & $1(50)$ & $1(50)$ & $0(0)$ & $0(0)$ & $0(0)$ & $0(0)$ & $0(0)$ & $2(2)$ & \multirow{4}{*}{-.027} & \multirow{4}{*}{.79} \\
\hline & Credit & $26(40.6)$ & $2(3)$ & $15(23.4)$ & 15 (23.4) & $1(1.6)$ & $0(0)$ & $1(1.6 \%)$ & $2(3)$ & $1(1.6)$ & $64(65)$ & & \\
\hline & Pass & $11(34.3)$ & $2(6.3)$ & $11(34.3)$ & $7(21.8)$ & $0(0)$ & $1(3.1)$ & $0(0 \%)$ & $0(0)$ & $0(0)$ & $32(33)$ & & \\
\hline Total & & 37 & 4 & 27 & 24 & 1 & 1 & 1 & 2 & 1 & $98(100)$ & & \\
\hline
\end{tabular}

\section{Discussion}

Over the past two decades, educational researchers and practitioners have confirmed that individuals not only differ in ability level, but also differ systematically in their patterns of behaviour or responses to similar situations thereby reflecting an underlying style. Consequently diagnosing students' learning styles and matching them to teaching methods (for example for a 'visual learner', presenting information through pictorial illustrations), has been proposed to greatly enhance learning. ${ }^{[11]}$ However, other scholars have rejected the value of learning styles in educational practice and claim that tailoring instruction to students' individual learning styles does not lead to better learning outcomes. ${ }^{[12]}$

Based upon the above discrepancy and as a means to building upon the important discourse, we conducted a study to test the hypotheses that there is no association between Nursing Students' academic performance and, their learning styles and intelligence types. From our study, both learn- ing styles and intelligence types showed negative correlation and no significant association with academic performance. There are two plausible reasons for this finding. Firstly, the teaching methods utilized for nursing students within the school of nursing could be varied and therefore capable of promoting learning across different learning styles and intelligence types without necessarily favouring a specific style or type. Secondly, as some scholar have asserted, ${ }^{[12]}$ probably teaching methods do not determine academic performance, meaning that there could be other factors that determine academic performance. However for a conclusion to be made as to whether or not learning styles or intelligence types do or do not determine academic performance, a randomized control trial study that can assign students to teaching methods of their preference and evaluate their academic performance against a certain baseline could be more conclusive. Our findings agree with those of other researchers for example Suliman ${ }^{[30]}$ in a study on the relationship between 
academic success and the two variables of learning styles and emotional social intelligence which was conducted at two colleges of nursing in Saudi Arabia. ${ }^{[30]}$ Findings of the study were that there was no significant relationship between learning styles and emotional social intelligence and academic success. ${ }^{[30]}$ These findings suggested that, there is no actual relationship between learning styles or emotional intelligence and academic success.

Gardner's Theory of Multiple Intelligences provides a theoretical foundation for recognizing the different abilities and talents of students. This theory acknowledges that while all students may not be verbally or mathematically gifted, children may have an expertise in other areas, such as music, spatial relations, or interpersonal knowledge. ${ }^{[3]}$ Therefore approaching and assessing learning in this manner allows a wider range of students to successfully participate in classroom learning. Furthering on this discussion, Armstrong and colleagues suggested that the theory of multiple intelligences proposes a major transformation in the way our schools are run. ${ }^{[33]}$ The theory suggests that teachers be trained to present their lessons in a wide variety of ways using music, cooperative learning, art activities, role play, multimedia, field trips, inner reflection, and much more so that each student has the opportunity to learn in ways harmonious with their unique minds. ${ }^{[33]}$ Similar to the findings on learning styles, our study revealed a negative correlation between nursing students' academic performance and their intelligence types. This pointed out to the fact that apart from intelligence types and as already indicated learning styles, there could be other factors that influence academic performance of nursing students which need to be explored.

For our study, in addition to testing for association between learning styles and intelligence types, and academic performance we also correlated academic performance with three demographic variables; age, gender and year of study. Only age showed a positive correlation and significant association with academic performance. It is worth indicating that at the University of Zambia, School of Nursing, there are two distinct categories of students; those who are enrolled with a basic qualification that is a Diploma in Nursing and those who are enrolled as school leavers without any prior qualification in Nursing. The first category comprises mature students mainly above 25 years while the second are young students mainly below 25 years.

\section{Conclussion}

From our study, participants had wide-ranging learning styles from unimodal to bimodal and trimodal styles although the majority were unimodal type of learners $82.6 \%$. Expectedly, majority of the unimodal learners were kinaesthetic $(35.7 \%)$ followed by reading and writing type of learners $(20.4 \%)$. On the other hand majority of the participants $37.8 \%$ had logical mathematical intelligence, followed by bodily-Kinaesthetic $27.6 \%$ while the combination of the two; Logical-mathematical and Bodily-kinaesthetic was the third commonest type of intelligence $24.5 \%$. Despite the varied range of both learning styles and intelligence types, both variables had negative correlation with academic performance. We therefore concluded that the negative correlation between learning styles and intelligence types, and academic performance could be an indication that the teaching methods utilized for nursing students are diverse and therefore capable of promoting learning across different learning styles and intelligence types without necessarily favouring a specific style or type. This finding supported the assertion by some scholars who have rejected the role of learning styles and intelligence types on academic performance. These findings suggest that there could be other factors that determine academic performance among nursing students for example in our study, age which was found to have a positive correlation and significant association with academic performance.

\section{CONFLICTS OF INTEREST Disclosure}

The authors declare that they have no competing interests.

\section{REFERENCES}

[1] Keefe JW. Learning styles theory \& practice. Reston, Virginia: National Association of Secondary School Principals. 1987.

[2] Larkin T, Budny D. Learning styles in the classroom: approaches to enhance student motivation and learning. Paper presented at ITHET 6th Annual International Conference; 2005. F4D1-F4D8.

[3] Silver HF, Strong RW, Perini MJ. Integrating learning styles and multiple intelligences. Educational Leadership. 2005; 55(1): 22-27.

[4] Griffiths C. 'Learning styles: traversing the quagmire' in S. Mercer, S. Ryan, and M. Williams (eds.). Psychology or Language Learn- ing: Insights from Research, Theory and Practice. London: Palgrave Macmillan. 2012.

[5] Foley I. Teacher learning style preferences, student learning style preferences and student reading achievement (Doctoral dissertation). Available from ProQuest Dissertation and theses databases. 1999.

[6] Collins J. Education techniques for lifelong learning: principles of adult learning. Radiographics. 2004; 24: 1483-9. PMid:15371622 https://doi.org/10.1148/rg.245045020

[7] Coffield F, Moseley D, Hall E, et al. Learning styles and pedagogy in post-16 learning: a systematic and critical review. Learn Skills Res Centre. 2004; 1-205. 
[8] Hilgerson-Volk K. Celebration students' diversity through learning styles. OSSC Bulletin. 1987; 30(9).

[9] Shah K, Ahmed J, Shenoy N, et al. How different are students and their learning styles? International Journal of Research in Medical Science. 2013; 1(3): 212-215

[10] Wingo OG. Analysis of learning preferences of adult learners. A Dissertation presented to the Graduate School of the University Florida. 1992.

[11] Sternberg RJ, Grigorenko EL, Zhang LF. Styles of learning and thinking matterin instruction and assessment. Perspectives on Psychological Science. 2008; 3(6): 486-506.

[12] Willingham DT. 'Do visual, auditory, and kinesthetic learners need visual, auditory, and kinesthetic instruction? American Education. 2005; 29(2): 31-5.

[13] Materna L. Jump start the adult learner: how to engage and motivate adults using brain - compatible strategies. Thousand Oaks CA: Sage; 2007.

[14] Mayzler A, McGann A. Tutor in a book: better grades as easy as 1-2-3. Avon, MA: Adams Media. 2010.

[15] Stash N. Incorporating cognitive/learning styles in a general purpose adaptive hypermedia system (Doctoral dissertation).

[16] Kapp K, Latham W, Latham H. Integrated learning for ERP success: A learning requirements planning approach. Boca Raton, FL: St Lucie Press; 2001.

[17] Blerkom D. College student skills: becoming a strategic learner (6th ed.). Boston. MA: Wassworth Cengage Learning. 2008.

[18] Conroy E. 20 Secrets to success with your child: wit and wisdom from a mom of 12. Bloomington, IN: Author House. 2007.

[19] Fleming N. Teaching and learning styles VARK strategies. Christchurch, New Zealand: Neil D Fleming. 2006.

[20] Bastable S. Nurse as educator: principles of teaching and learning for nursing practice (3rd ed.). Sudbury, MA: Jones and Bartlett. 2008.

[21] Nilson L. Teaching at its best: a research-based resource for college instructors (3rd ed.). San Francisco, CA: Jossy-Bass. 2010.
[22] Gerdy K. Making the connection: learning style theory and the legal research curriculum. In G. Hill., D. Sears., \& L. Lyman. (Eds). Teaching legal research and providing access to electronic resources (pp. 71-94). New York: Haworth Information Press; 2001.

[23] Dreeben O. Patient education in rehabilitation. Sudbury, Mass: Jones and Bartlett Publishers. 2010.

[24] Lobb N. Learning strategies for school, home, \& work. Portland, Maine: J. Weston Walch, Publisher. 2003.

[25] Guffanti S. Homeschooling: a natural fit for the kinaesthetic child. 2009. Available from: http://aufiles.creation.com/image s/pdfs/home-school-corner/special-needs/6664hs-kin esthetic.pdf

[26] Reiff J. What Research Says to the Teacher: Learning Styles. Washington, DC: National Education Association. 1992.

[27] Salehi SH Shahnooshi EH. Nursing Students' Preferred Learning Styles. Journal of Medical Education. 2007; 11(3\&4): 5-31.

[28] Kolb D. Experiential learning: experience as the source of learning and development. Eaglewood Cliffs (NJ): Prentice-Hall Inc. 1984.

[29] Gardner H. Frames of mind: The theory of multiple intelligences. Basic books. New York. 2011.

[30] Suliman WA. The relationship between learning styles, emotional social intelligence, and academic success of undergraduate nursing students. Journal of Nursing Research. 2010; 18(2): 136-43. PMid:20592659 https://doi.org/10.1097/JNR.0b013e3181 dda797

[31] Yeghiazarian A, Fitkov-Norris ED. Validation of VARK Learning Modalities Questionnaire using Rasch analysis. Conference series 588 (2015) 012048.

[32] Ferrándiz C. Evaluation and development of cognitive competency: A study based on the model of the multiple intelligences. National Prize of Education Research. Madrid: CIDE-MEC. 2004

[33] Armstrong T. Multiple intelligences in the classroom. ASCDAlexandria, Virginia. USA. 2009; 3rd Edition. 